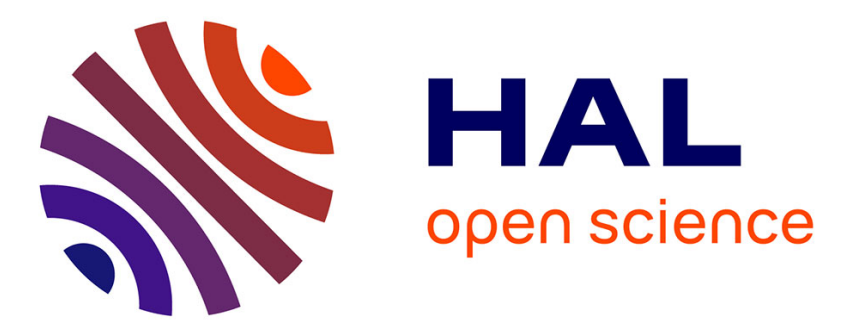

\title{
The 1997 Umbria-Marche, Italy, earthquake sequence : a first look at the main shocks and aftershocks
}

\author{
A. Amato, R. Azzara, C. Chiarabba, G.B. Cimini, M. Cocco, M. Dibona, L. \\ Margheriti, S. Mazza, F. Mele, G. Selvaggi, et al.
}

\section{- To cite this version:}

A. Amato, R. Azzara, C. Chiarabba, G.B. Cimini, M. Cocco, et al.. The 1997 Umbria-Marche, Italy, earthquake sequence: a first look at the main shocks and aftershocks. Geophysical Research Letters, 1998, 25 (15), pp.2861-2864. 10.1029/98GL51842 . hal-00497729

\section{HAL Id: hal-00497729 \\ https://hal.science/hal-00497729}

Submitted on 8 Feb 2021

HAL is a multi-disciplinary open access archive for the deposit and dissemination of scientific research documents, whether they are published or not. The documents may come from teaching and research institutions in France or abroad, or from public or private research centers.
L'archive ouverte pluridisciplinaire HAL, est destinée au dépôt et à la diffusion de documents scientifiques de niveau recherche, publiés ou non, émanant des établissements d'enseignement et de recherche français ou étrangers, des laboratoires publics ou privés. 


\title{
The 1997 Umbria-Marche, Italy, earthquake sequence: a first look at the main shocks and aftershocks
}

\author{
A. Amato, R. Azzara, C. Chiarabba, G.B. Cimini, M. Cocco, M. Di Bona, L. \\ Margheriti, S. Mazza, F. Mele, G. Selvaggi, A. Basili, E. Boschi \\ Istituto Nazionale di Geofisica, Rome, Italy
}

F. Courboulex, A. Deschamps, S. Gaffet

Géosciences Azur, France

G. Bittarelli, L. Chiaraluce, D. Piccinini, M. Ripepe

Università di Camerino, Italy

\begin{abstract}
A long sequence of earthquakes, six with magnitudes between 5 and 6 , struck Central Italy starting on September 26, 1997, causing severe damages and loss of human lives. The seismogenic structure consists of a NW-SE elongated fault zone extending for about $40 \mathrm{~km}$. The focal mechanisms of the largest shocks reveal normal faulting with NE-SW extension perpendicular to the trend of the Apennines, consistently with the Quaternary tectonic setting of the internal sector of the belt and with previous earthquakes in adjacent regions. Preliminary data on the main shocks and aftershocks show that extension in this region of the Apennines is accomplished by normal faults dipping at low angle $\left(\sim 40^{\circ}\right)$ to the southwest, and confined in the upper $\sim 8 \mathrm{~km}$ of the crust. These normal faults might have reactivated thrust planes of the Pliocene compressional tectonics. The aftershock distribution and the damage patterns also suggest that the three main shocks ruptured distinct 5 to $15 \mathrm{~km}$-long fault segments, adjacent and slightly offset from one another.
\end{abstract}

\section{Introduction}

On September 26, 1997, at 00:33 UTC (02:33 local time), central Italy was struck by a strong earthquake, which was followed by a stronger shock nine hours later (09:40 UTC). Both shocks ( $M_{W} 5.7$ and 6.0) caused severe damage and loss of human lives in a region between Umbria and Marche, and were felt by millions of people in central Italy, including Roma and Firenze. Eleven people died, and unique masterpieces of Italian architectural and painting art were destroyed or strongly damaged, for example in Assisi and Foligno (Umbria). Earthquakes of this size are common in the historical catalogue of the Umbria-Marche region, although none has been reported in the epicentral area of the 1997 shocks (Boschi et al., 1995). The surrounding regions were repeatedely struck by strong earthquakes in the past, both to the north $(1279,1747,1751)$ and to the south $(1328$, 1703, 1730) (Figure 1). At present, the Umbria-Marche Apennines are characterized by diffuse crustal seismicity,

Copyright 1998 by the American Geophysical Union.

Paper number 98GL51842.

0094-8534/98/98GL-51842\$05.00 with thousands of earthquakes located by the national network (RSNC) of the Istituto Nazionale di Geofisica (ING) in the past two decades. Two main sequences occurred in the past twenty years at about $30 \mathrm{~km}$ from the region of Colfiorito, to the northwest (1984 at Gubbio-Perugia, $\mathrm{M}_{S} 5.3$ ) and to the south (1979 at Norcia, $\mathrm{M}_{S} 5.8$ ) (Deschamps et al., 1984; Haessler et al., 1988). Both these earthquakes had normal faulting mechanisms (Figure 1), consistent with the present tectonic setting of the internal sector of the northern Apennine arc (Anderson and Jackson, 1987; Frepoli and Amato, 1997; Montone et al., 1997). Differently from the recent seismic sequences of the region (1979 and 1984), the one which started last September has an unusually high number of strong shocks. Five exceeded $\mathrm{M}_{L} 5$, and more than 20 exceeded $M_{L} 4$ (Figure 2). This paper describes the distribution of main shocks and aftershocks, as determined from the ING national network and from a dense local network installed immediately after the first shocks.

\section{The main shocks}

On September 3, 1997 (at 22:07 UTC) a $\mathrm{M}_{L} 4.5$ earthquake in the plain of Colfiorito triggered a sequence of aftershocks which lasted for about three weeks, with a normal decay in the number and magnitudes of shocks (Figure 3). At 00:33 UTC on Sep. 26, a $M_{W} 5.7$ shock occurred at about the same location and at $\sim 7 \mathrm{~km}$ depth, with a normal faulting mechanism. It caused severe damage in the small villages located to the south of the epicenter. The second strong shock occurred at 09:40 UTC $\left(\mathrm{M}_{W} 6.0\right), 3 \mathrm{~km}$ WNW of the first. Both earthquakes were located with data from the ING national network, but only for the first one could we use data from four close stations. For this reason, the shock of 09:40 has the largest location uncertainties, particularly in depth (Table 1). The two earthquakes had similar focal mechanisms, with NW-trending normal faulting planes (Ekstrom et al., 1998). Contrary to what was observed during the first earthquake of the night, the second shock caused destruction towards the north, suggesting that the two earthquakes ruptured in opposite directions, as also indicated by strong motion recordings and by the analysis of regional broad-band data (N.A. Pino, pers. comm.) To test this hypothesis further, we compare the aftershocks located by RSNC in the nine hours following each of the two 
Table 1. Hypocentral parameters of the six largest shocks

\begin{tabular}{|c|c|c|c|c|c|c|c|c|}
\hline Time UTC & Lat. & Long. & Depth, km & Mo, dyne $\mathrm{cm}^{\mathrm{a}}$ & $M_{L}^{\mathrm{a}}$ & ERH, $\mathbf{k m}$ & $\mathrm{ERZ}, \mathbf{k m}$ & Stat $^{b}$ \\
\hline $97 / 09 / 2600: 33$ & $43^{\circ} 01.35^{\prime}$ & $12^{\circ} 53.50^{\prime}$ & 6.6 & $4.010^{24}$ & 5.6 & 0.6 & 0.9 & $14(4)$ \\
\hline $97 / 09 / 26 \quad 09: 40$ & $43^{\circ} 01.83^{\prime}$ & $12^{\circ} 51.73^{\prime}$ & 5.7 & $12.010^{24}$ & 5.8 & 0.8 & 2.0 & $6(1)$ \\
\hline $97 / 10 / 0308: 55$ & $43^{\circ} 01.97^{\prime}$ & $12^{\circ} 50.25^{\prime}$ & 6.2 & $0.910^{24}$ & 5.0 & 0.3 & 0.6 & $29(24)$ \\
\hline $97 / 10 / 06 \quad 23: 24$ & $43^{\circ} 01.13^{\prime}$ & $12^{\circ} 50.27^{\prime}$ & 7.1 & $1.710^{24}$ & 5.4 & 0.3 & 0.5 & $29(24)$ \\
\hline $97 / 10 / 1211: 08$ & $42^{\circ} 54.62^{\prime}$ & $12^{\circ} 56.78^{\prime}$ & 5.9 & $0.810^{24}$ & 5.1 & 0.3 & 0.2 & $28(23)$ \\
\hline $97 / 10 / 1415: 23$ & $42^{\circ} 55.14^{\prime}$ & $12^{\circ} 55.56^{\prime}$ & 6.6 & $3.410^{24}$ & 5.5 & 0.4 & 0.4 & $28(22)$ \\
\hline
\end{tabular}

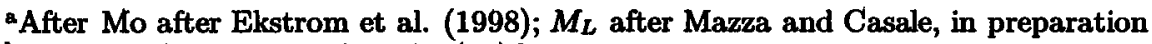

bNumber of stations within $100(20) \mathrm{km}$.

main shocks. Figure 3 shows that early aftershocks of the first earthquake are concentrated to the east of the main shock epicenter, whereas aftershocks following the second shock are mostly located to the north. This strenghtens the hypothesis that the two shocks ruptured, in opposite directions, two adjacent fault segments. Interestingly, the region between the two main rupture zones was affected by the foreshock sequence of Sep. 3 (Figure 3). Four more strong

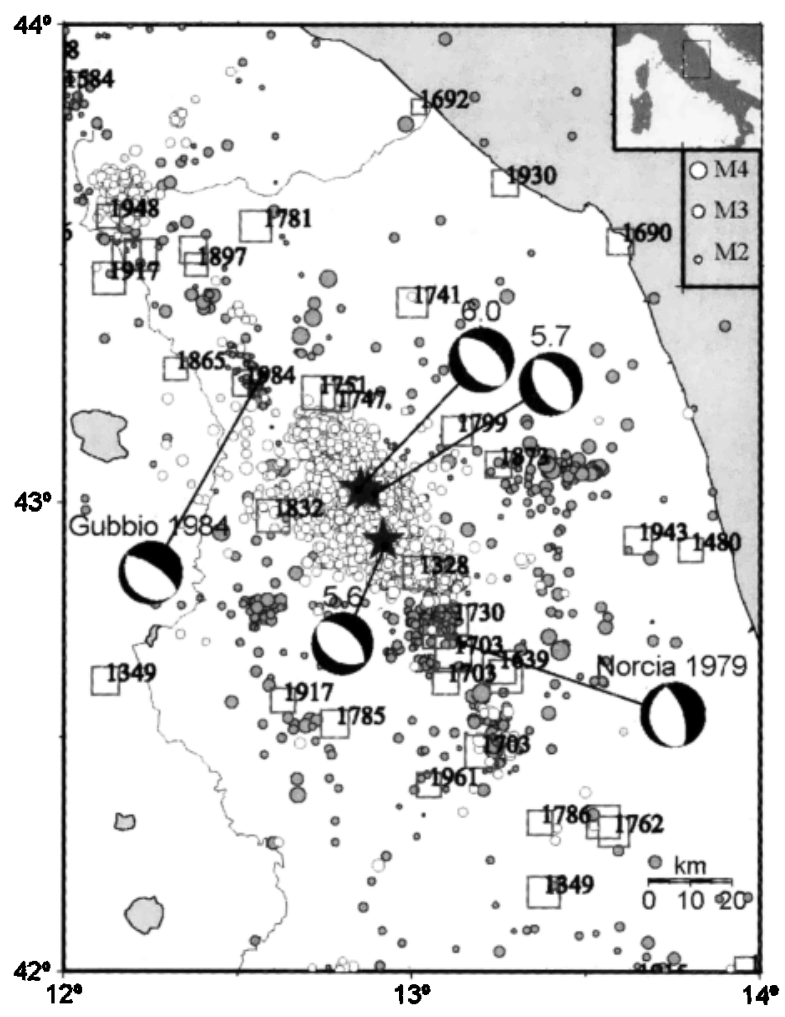

Figure 1. Main shocks (stars) and aftershocks located by the RSNC from Sep. 26 to Dec. 31, 1997, and focal mechanisms from Ekstrom et al. (1998). Also shown are major historical earhquakes in the last 700 years (squares, numbers indicate the years of occurrence after Boschi et al., 1995), background seismicity from the ING bulletins (19931997, grey circles), aftershocks and focal mechanisms of the 1979 Norcia and the 1984 Gubbio-Perugia earthquake. shocks (Mw between 5.2 and 5.7) occurred in the following twenty days (Oct. 3, 7, 12, 14), all with similar focal mechanisms (Ekstrom et al., 1998). The first two were located close to those of Sep. 26, whereas the latter two occurred about $15 \mathrm{~km}$ to the southeast. The total extent of the activated area thus became about $40 \mathrm{~km}$.

\section{Aftershock distribution}

A dense temporary network of 26 three- and six-component digital seismic stations (Figure 4) was deployed a few hours after the first shocks by teams of the ING, the Géosciences Azur, France (GA), and the Universitá di Camerino (UC) (Figure 4). Several thousands of aftershocks were recorded by the temporary network from Sep. 26 to Nov. 3, 1997. The temporal distribution of seismicity (Fig-

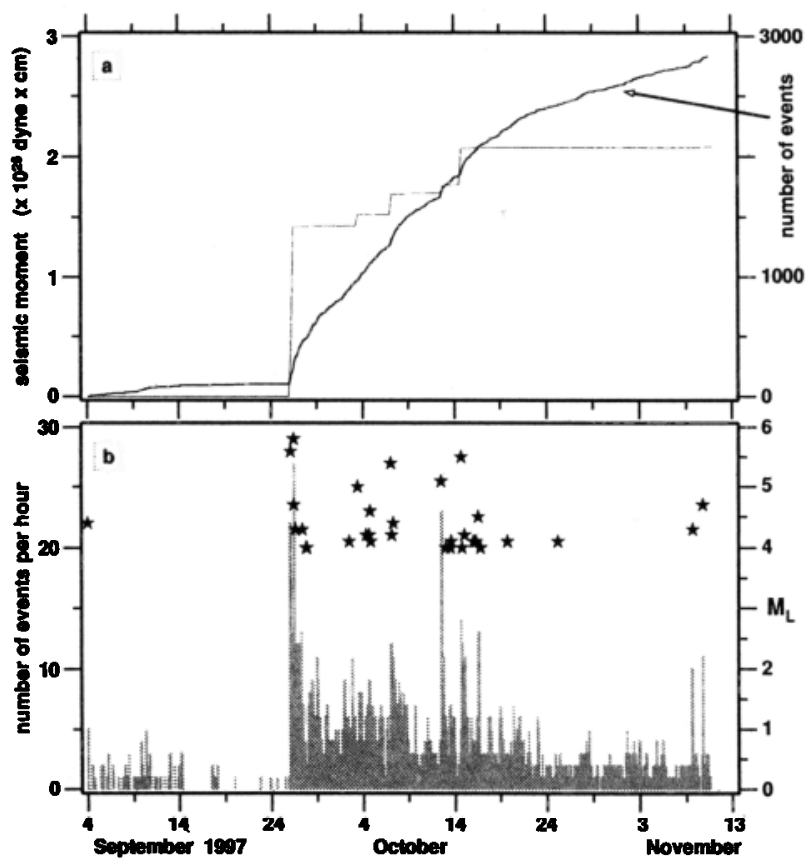

Figure 2. Temporal distribution of seismicity from Sep. 3 through Nov. 3, 1997. Top: cumulative number of earthquakes with $M_{L}>2.5$ and related cumulative seismic moment. Bottom: number of earthquakes per hour and magnitude of the largest shocks ( $M_{L} \geq 4$, black stars). 

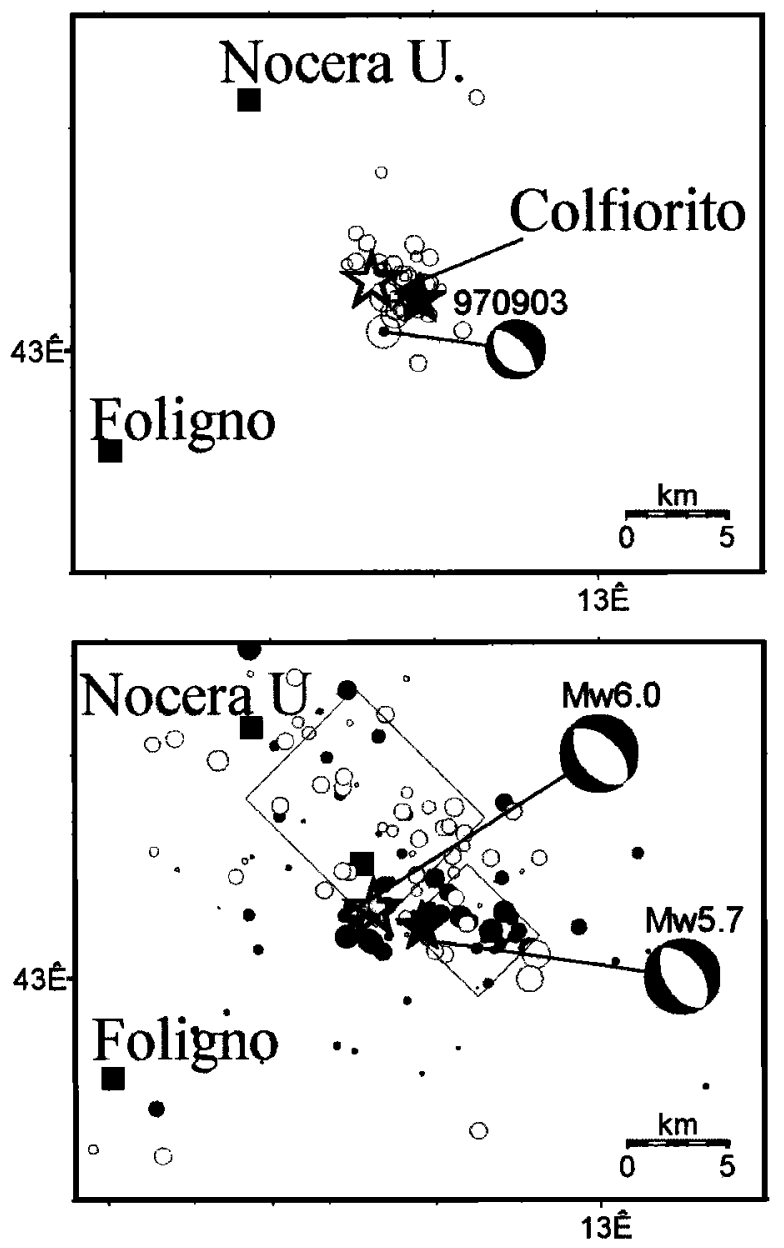

Figure 3. Top: epicenters of the Sep. 3, $1997 M_{L} 4.5$ foreshock sequence compared to those of the two shocks of Sep. 26 (stars). Bottom: aftershocks of the first large shock of the night (black circles: 26 Sep. 00:33 to 09:39 UTC) and of the second large shock of the morning (grey circles: 26 Sep. 09:40 to 18:40 UTC), as determined by the permanent network. The boxes indicate the approximate extent of the two rupture areas. Focal mechanisms from Ekstrom et al., 1998.

ure 2) shows that some of the large shocks were followed by an increase in the number of earthquakes, suggesting that the whole sequence consists of a series of different rupture episodes. However, not all the large shocks were followed by an evident increase in seismicity, as for instance the Oct. 3 event (Figure 2 and Table 1), which occurred near an area previously ruptured by the largest earthquakes. About 2,550 aftershocks have been located with data of the local network. Figure 4 shows the 1,747 best located earthquakes (with formal location errors less than $1 \mathrm{~km}$ ), whose distribution delineates a NW-SE trending fault zone, elongated for about $40 \mathrm{~km}$, and extending for 5 to $15 \mathrm{~km}$ in the perpendicular direction. The NW-SE trend is consistent with the fault plane solutions of the largest shocks and with previous earthquakes (Figure 1). In a vertical section crossing the fault zone perpendicular to its trend (Figure 4) the main shock hypocenters are located at the base of the aftershock zone, at 6-7 km depth. According to the aftershock distribution at depth, the dip of the fault is $\sim 35^{\circ}$ to the SW, slightly lower than the one inferred from the focal mechanism $\left(42^{\circ}\right)$.

\section{Discussion and Conclusion}

In the region, the two main NW-trending normal faults active in the Quaternary are located at the eastern boundary of the Colfiorito basin, and a few $\mathrm{km}$ southwest of it, respectively (Calamita and Pizzi, 1994; Cello et al., 1997). Figure 4 shows that the rupture of the $M_{W} 6.0$ shock nucleated at about $6 \mathrm{~km}$ depth and propagated up-dip and to the north, as previously discussed. The rupture probably stopped very close to the surface, as suggested by both the aftershock and geodetic data (Hunstad, et al., 1998). Based on these simple geometric considerations and a comparison with the mapped faults, it seems likely that no true surface faulting occurred. The observed cracks and fault reactivations, studied by Cinti et al. (1998), Galli et al. (1998) and
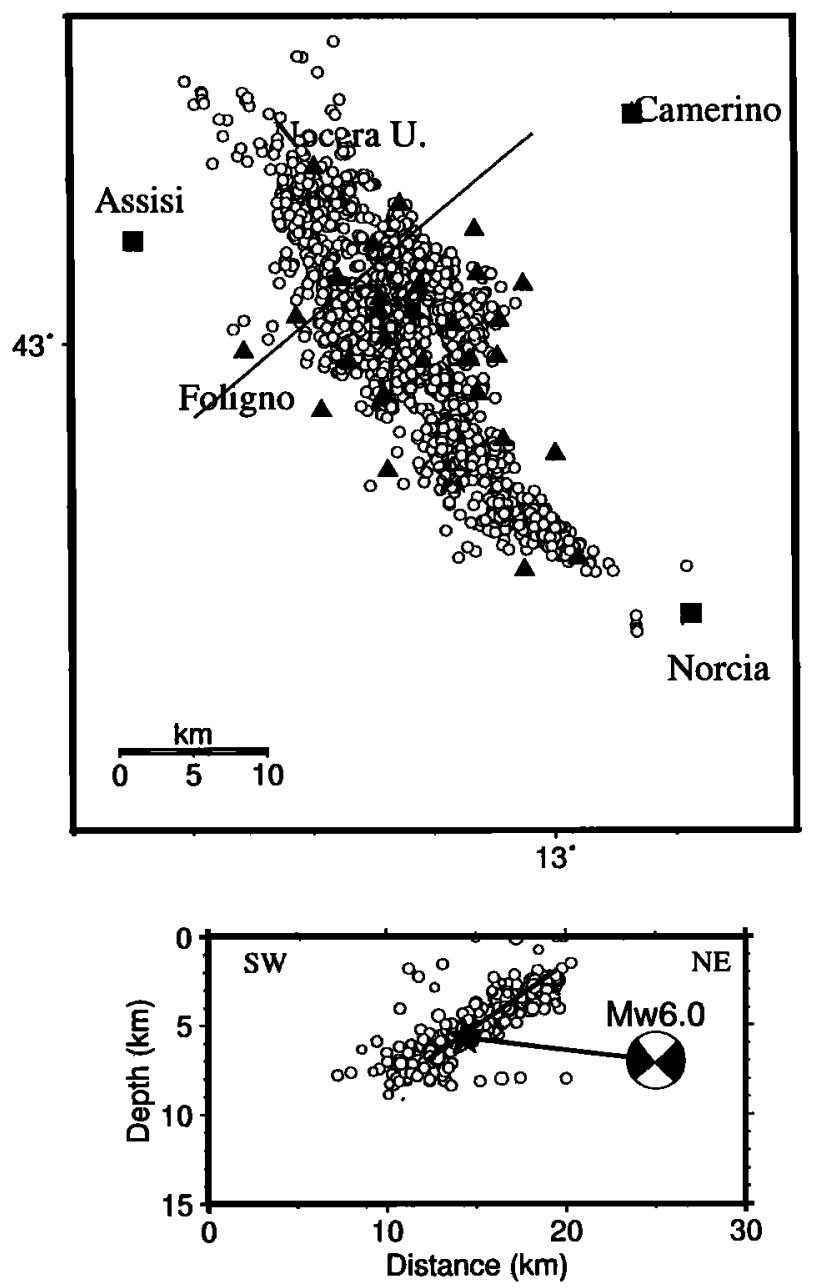

Figure 4. Epicentral distribution (top) and SW-NE vertical section (bottom) of 1,747 selected aftershocks located by the temporary network (with location errors less than 1 $\mathrm{km}$ ). Earthquakes within $\pm 2 \mathrm{~km}$ from the profile are plotted in the section. In the map the distribution of the temporary (black triangles) and of the permanent network (squares) are shown. 
Vittori et al. (1998) could represent the localized response of the shallowest part of the crust to extension occurring at depth.

Another interesting issue raised by this earthquake sequence is the role played by normal faults in the active tectonics of the region. It is a matter of debate whether the regional stress is dominated by crustal extension perpendicular to the Apennines, as suggested by seismological and borehole breakout data (Anderson and Jackson, 1987; Haessler et al., 1988; Frepoli and Amato, 1997; Montone et al., 1997), or whether the normal faults act as a response to different processes, such as pull-apart type tectonics in a strike-slip stress regime (Cello et al., 1997).

Within uncertainties due to the preliminary nature of the data analyzed to date, the following scenario is suggested for the Umbria-Marche earthquake sequence. (a) It is confirmed that a process of NE-SW extension is active in the region. The similarity of the focal mechanisms to those determined for recent earthquakes in adjacent regions (Figure 1) suggests that this extensional stress regime is uniform in this area of the Apennines. (b) The three largest shocks have ruptured distinct, adjacent, sub-parallel normal fault segments with a rather constant NW-SE trend. These main segments appear to be laterally offset, particularly the third and southernmost one, for which a rightlateral stepping of about $5 \mathrm{~km}$ is suggested by aftershock locations. (c) The total extent of the aftershock zone (40 $\mathrm{km}$ ) is larger than the cumulative length of the individual ruptures of the largest shocks (25-30 km), considering their seismic moments. Around the main ruptures, at least three areas with diffuse seismicity are evident, namely the SE edge of the structure, the region north of Sellano, and that between the two main shock epicenters of Sep. 26, where the foreshock sequence of Sep. 3 occurred. (d) The normal fault planes which ruptured during the largest shocks are those dipping to the southwest. Dip of the distribution is about $\sim 35^{\circ}$, in good agreement with the SW-dipping plane of the focal mechanisms. In view of this, a plausible hypothesis is that the faults ruptured pre-existing thrust planes inherited from the Pliocene compressional tectonics of the Apennines (Bally et al., 1986), which are clearly visible in the few seismic profiles available for the region.

Acknowledgments. The authors thank the ING bulletin staff who helped in field work and analysed the RSNC data, and the ING technical laboratory staff for help in field work. The $M_{L}$ values were kindly provided by P. Casale. Dr. F. Evison and two anonymous referees are thanked for reviewing the manuscript.

\section{References}

Anderson, H. J., and J. A. Jackson, Active tectonics of the Adriatic region, Geophys. J. R. Astron. Soc., 91, 937-983, 1987.
Bally, A. W., L. Burbi, C. Cooper, and R. Ghelardoni, Balanced sections and seismic reflection profiles across the central Apennines, Mem. Soc. Geol. It., 35, 257-310, 1986.

Boschi, E., G. Ferrari, P. Gasperini, E. Guidoboni, G. Smriglio, and G. Valensise, Catalogo dei forti terremoti in Italia dal 461 a.C. al 1980, Pubblicazione dell'Istituto Nazionale di Geofisica, 973 pp., 1995.

Calamita, F., and A. Pizzi, Recent and active extensional tectonics in the southern Umbro-Marchean Apennines (central Italy), Mem. Soc. Geol. It., 48, 541-548, 1994.

Cello, G., S. Mazzoli, E. Tondi, and E. Turco, Active tectonics in the Central Apennines and possible implications for seismic hazard analysis in peninsular Italy, Tectonophysics, 272, 4368, 1997.

Cinti, F., L. Cucci, F. Marra and P. Montone, Preliminary analysis of the source effects producued by the Umbria-Marche seismic sequence and possible seismotectonic implications (abstract), European Geophysical Society Annual Conference, Nice, France, 1998.

Deschamps, A., G. Iannaccone and R. Scarpa, The Umbrian earthquake (Italy) of 19 September 1979, Annales Geophysicae, 2, 1, 29-36, 1984.

Ekstrom, G., A. Morelli, A. M. Dziewonski, E. Boschi, Moment tensor analysis of the Umbria-Marche earthquake sequence of September-October 1997, Geophys. Res. Lett., in press, 1998.

Frepoli, A., and A. Amato, Contemporaneous extension and compression in the North Apennines from earthquake fault plane solutions, Geophys. J. Int., 129, 368-388, 1997.

Galli, P., R. Basili, V. Bosi, F. Galadini, M. Meghraoui, P. Messina, M. Moro and A. Sposato, The central Italy earthquake of Sptember-October 1997: geological effects and seismotectonic hypotheses (abstract), European Geophysical Society Annual Conference, Nice, France, 1998.

Haessler, H., R. Gaulon, L. Rivera, R. Console, M. Frogneux, C. Gasparini, L. Martel, G. Patau, M. Siciliano and A. Cisternas, The Perugia (Italy) earthquake of 29 April 1984: a microearthquake survey, Bull. Seismol. Soc. Am., 78, 6, 1948$1964,1988$.

Hunstad, I., M. Anzidei, P. Baldi, A. Galvani and A. Pesci (1998) GPS observations of co-seismic displacement of the UmbriaMarche seismic sequence (abstract), European Geophys. Soc. Annual Conference, Nice, France, 1998.

Montone, P., A. Amato, A. Frepoli, M. T. Mariucci, and M. Ce saro, Crustal stress regime in Italy, Annali di Geofisica, $X L$, 3, 741-757, 1997.

Vittori, E., G. Cello, G. Deiana et al. (1998) Geological effects of the September 26, 1997 earthquakes in central Italy (abstract), European Geophysical Society Annual Conference, Nice, France, 1998.

A. Amato, Istituto Nazionale di Geofisica, Via di Vigna Murata, 605, Roma, Italy. (e-mail: amato@ingrm.it)

(Received February 9, 1998; revised May 6, 1998; accepted May 19, 1998.) 